\title{
Effects of Soil Temperature during Fire on Seed Survival in Florida Sand Pine Scrub
}

\author{
Mary E. Carrington \\ Science Division, Governors State University, University Park, IL 60484, USA \\ Correspondence should be addressed to Mary E. Carrington, m-carrington@govst.edu \\ Received 21 July 2009; Accepted 22 December 2009 \\ Academic Editor: Terry L. Sharik \\ Copyright () 2010 Mary E. Carrington. This is an open access article distributed under the Creative Commons Attribution License, \\ which permits unrestricted use, distribution, and reproduction in any medium, provided the original work is properly cited. \\ Soil temperatures recorded with thermocouples and temperature-sensitive paints were quantified during Florida sand pine scrub \\ prescribed fires at Ocala National Forest and Archbold Biological Station in May 1993. Thermocouples and glass petri dishes \\ painted with temperature-sensitive paints and containing seeds of Eriogonum floridanum were placed at $0 \mathrm{~cm}$ and $2 \mathrm{~cm}$ depth, and \\ in vegetated and open microsites. Maximum temperatures were higher and peak temperature durations shorter at $0 \mathrm{~cm}$ than at \\ $2 \mathrm{~cm}$ depth. Temperatures did not differ between microsites during the Ocala fire, but were higher in open microsites during the \\ Archbold fire, probably due to combustion of well-aerated litter. Maximum temperatures of petri dishes were lower than those of \\ adjacent thermocouples due to time required to melt paints. All Eriogonum seeds recovered from petri dishes after the Archbold \\ fire failed to germinate. Germination was quantified for Eriogonum floridanum and Garberia heterophylla seeds heated to $100^{\circ} \mathrm{C}$ \\ and $60^{\circ} \mathrm{C}$ under laboratory conditions. Seeds failed to germinate at $100^{\circ} \mathrm{C}$, while germination was similar to controls for seeds \\ exposed to $60^{\circ} \mathrm{C}$. Results from this study suggest that small-scale spatial variation temperatures at the soil surface during fires is \\ essential for seed survival and subsequent post-fire recruitment.
}

\section{Introduction}

Seeds that survive fires in the soil contribute to postfire recruitment to varying degrees among fire-influenced communities $[1,2]$. The capacity of species in these communities to establish seedlings after fire from seeds in a soil seed bank should be influenced by several factors including (1) magnitude and duration of high or elevated temperatures during fire at soil depths and in microsites where viable seeds are located, and (2) seed germination responses to elevated temperatures.

A large volume of field research and laboratory research has been conducted on temperatures reached during natural fires [3-24], and on seed germination responses to elevated temperatures $[4,6,9,13,16,25-35]$. These two lines of research usually have been mutually exclusive, and have concentrated largely on Mediterranean-climate ecosystems and their species.

Researchers generally have used either temperaturesensitive paints or thermocouples to quantify soil temperatures reached during fires. Although recorded temperatures have varied among ecosystems and with differences in burning conditions, several patterns have been consistent across studies. Maximum soil temperatures generally decrease as depth in the soil increases, but durations of elevated temperatures increase $[3,6,9,12,13,16-19]$. Soil temperatures reached during fires also tend to vary with microsites, with temperatures in open microsites lower than temperatures in microsites with higher fuel accumulations $[12,15]$.

In laboratory germination studies, plant species from several ecosystems have demonstrated positive germination responses after being exposed to temperatures typically reached during fires. Taxa or functional groups with this response include legumes in the southeastern United States, California, and Australia [9, 13, 17, 25, 28, 29, 32]; obligately seeding shrubs in California chaparral and in southern France $[25,27,30,34]$, and annual species in California chaparral $[25,29]$. Other species, however, have responded to elevated temperatures with decreased or no germination. Some functional groups that have demonstrated this response are herbaceous perennials [29] and other species that do not establish seedlings after fires [30]. 
This study documents soil temperatures during fires, and seed germination responses to elevated temperatures in sand pine scrub, a community occurring primarily in Florida on well-drained sandy soils of former Miocene to Pleistocene dunes. Sand pine scrub is dominated by woody shrubs including several oak species (Quercus spp.), rusty lyonia (Lyonia ferruginea), Florida rosemary (Ceratiola ericoides), and occasionally scrub hickory (Carya floridana); often an overstory of sand pine (Pinus clausa) is present [36]. Smallstatured $(<2 \mathrm{~m}$ tall) perennial species are usually sparse, and annual species are virtually absent.

Natural fires are lightning-initiated, and usually occur during the wet growing season during the months of April through July. Although frequency of lightning strikes is extremely high in Florida [37], sand pine scrub fires occur infrequently, approximately every 10 to 100 years. A combination of fuel characteristics and season of burning influences fire frequency-ground litter and other fine fuels are often sparse, most living vegetation is neither highly flammable nor easily ignited, and fuels are rarely dry during the lightning season. Consequently, fires tend to occur under extreme conditions of high fuel buildup, dry weather, or high winds, and often are intense [36].

As in other fire-influenced communities, plant species in sand pine scrub vary in their responses to fire. Most woody shrub species resprout and do not establish seedlings immediately following fires. In contrast, seedling establishment occurs primarily or exclusively after fire for some plant species that are killed by fire (e.g., Pinus clausa, Ceratiola ericoides, Dicerandra frutescens, Calamintha ashei $[36,38-40])$, as well as for some small-statured species that resprout following fire (e.g., Eriogonum floridanum, Garberia heterophylla $[41,42])$.

Although heat- and smoke-induced germination have not been documented in sand pine scrub as in some other fire-influenced communities [33, 43], seeds of some sand pine scrub species germinate after surviving fire in a soil seed bank $[39,44]$. In a recent study conducted at Archbold Biological Station, viable seeds were present in soil samples collected less than three months after fires, from $0-7 \mathrm{~cm}$ depth in the soil (Kohfeldt personal communication).

Temperatures reached during fires and germination responses to those temperatures are relatively unknown for sand pine scrub. Only one other study has measured temperatures at the soil surface during a sand pine scrub fire [24], and germination responses to high temperatures of most species have not been studied. Additional information on soil temperatures during fires and germination responses after fires should further elucidate the plant community response to fire in sand pine scrub, and could potentially increase effectiveness of rare species conservation through use of fire.

The first of two objectives of this study was to measure soil temperatures at different depths and in different microsites during fires in sand pine scrub. Lower peak soil temperatures and longer temperature durations were expected with increasing depth in the soil, as documented in other studies. Spatial patterns of combustible fuel in sand pine scrub are defined primarily by a widespread matrix of woody shrub vegetation underlain by moderate amounts of ground litter, interspersed with canopy openings with little or no litter. In this study, soil temperatures in microsites under vegetation (e.g., shrubs) were expected to be higher than those in openings.

The second objective of this study was to quantify germination responses of two small-statured perennial species after exposing the seeds to temperatures typically reached during sand pine scrub fires. Small-statured perennial species were chosen for study because much of the postfire seedling establishment response in sand pine scrub is attributable to species from this general group [42]. The two study species (hereafter referred to by their generic names), Eriogonum floridanum (Polygonaceae; Reveal 1981) and Garberia heterophylla (Asteraceae), were chosen because (1) both species establish seedlings primarily after fire; (2) although both species are relatively common locally, they are endemic to Florida, occur primarily in sand pine scrub, and are subjects of conservation concern (Eriogonum floridanum is federally listed as threatened).

Eriogonum is an herbaceous perennial and Garberia a woody shrub; both species have strong postfire resprouting and flowering responses [42]. As documented for other herbaceous perennials, germination was expected to decrease for Eriogonum seeds after exposure to an elevated temperature at any depth in the soil. Seeds of resprouting shrub species have exhibited a variety of responses to high temperatures and to high temperatures in combination with smoke $[45,46]$, making the Garberia germination response in this study potentially less predictable. Consequently, in this study Garberia seed germination was expected to decrease, remain unchanged, or possibly increase after exposure to an elevated temperature at any depth in the soil.

\section{Materials and Methods}

2.1. Field Experiments. Study areas were sand pine scrub sites at Ocala National Forest in Marion County, Florida $\left(29^{\circ}\right.$ $08^{\prime}, 81^{\circ} 45^{\prime}$ ) and Archbold Biological Station in Highlands County, Florida $\left(27^{\circ} 15^{\prime}, 81^{\circ} 15^{\prime}\right)$. The Ocala site and Archbold site last burned in 1935 and 1927, respectively. Both sites had a dense shrub layer consisting primarily of several species of oaks (Quercus spp.). Overstories differed in the two sites, however; sand pine was the only species in the overstory at Ocala, while at Archbold sand pines were interspersed with south Florida slash pines (Pinus elliottii var. densa).

Controlled burns were conducted at the Ocala and Archbold sites on May 10, 1993 and May 25, 1993, respectively. Before each fire, a datalogger (21X Micrologger, Campbell Scientific, Inc.) connected to 16 copper-constantan, $0.51 \mathrm{~mm}$ diameter thermocouples via insulated leads was buried in the site to be burned. The thermocouple leads were 1.5-4 m long, and were buried approximately $2 \mathrm{~cm}$ deep; the datalogger was placed in a fiberglass case and buried approximately $50 \mathrm{~cm}$ deep.

Each thermocouple was placed either at the soil surface or at $2 \mathrm{~cm}$ depth, and either in an open microsite or under vegetation. The $2 \mathrm{~cm}$ depth was chosen because seeds typically are 
found at this depth [47, Kohfeldt personal communication], yet were expected to be relatively insulated from high surface temperatures reached during a fire. Each depth-microsite combination was replicated four times through placement of individual thermocouples. Adjacent to each thermocouple, a glass petri dish containing 10 Eriogonum seeds was placed at the same soil depth and microsite. In each petri dish, Eriogonum seeds were placed on top of a layer of sand completely covering the bottom of the petri dish. Six petri dishes with Eriogonum seeds also were placed at a nearby control site that did not burn.

At Archbold the sides of each petri dish were painted with 19 temperature-sensitive paints (Tempilaq, Tempil Division, Big Three Industries, Inc.). Manufacturer-specified melting temperatures of paints ranged from $37.8^{\circ} \mathrm{C}$ to $815.6^{\circ} \mathrm{C}$. In addition to petri dishes adjacent to thermocouples, petri dishes also were placed throughout the site so that each depth-microsite combination was replicated eight additional times.

During each fire, the datalogger recorded thermocouple temperatures every five seconds. Temperature recording occurred from 90 minutes before the fire until 90 minutes after the flame front went through at the Ocala site, and from 90 minutes before the fire to 60 minutes after the flame front went through at Archbold.

After each fire, the datalogger and all petri dishes were recovered. Intact seeds were extracted from soil in the petri dishes, and were classified as charred or noncharred. All noncharred seeds were placed on moist filter paper in clean petri dishes, and observed for germination for one month. Viability of non-germinated seeds was assayed with a tetrazolium test [48]. At Archbold, maximum temperature reached during the fire was quantified for each petri dish by determining which temperature-sensitive paints melted.

Data on thermocouple maximum temperatures and temperature durations were analyzed separately for the Archbold and Ocala fires. Analyses of variance were conducted on rank-transformed maximum thermocouple temperatures to detect differences due to depth in the soil and microsite [49]. Temperature duration was defined for each thermocouple as the length of time that $75 \%$ of the maximum thermocouple temperature was maintained or exceeded. KolmogorovSmirnov tests were used to compare median temperature durations between thermocouples placed at the soil surface and those placed at $2 \mathrm{~cm}$ depth [50].

Maximum temperatures during the Archbold fire of petri dishes placed at the soil surface and at $2 \mathrm{~cm}$ depth were compared using a chi-square test, and a $t$-test was used to compare maximum temperatures of petri dishes and adjacent thermocouples. Data from both fires on Eriogonum seeds recovered from petri dishes were combined to determine the immediate fire effect on the seeds. Numbers of petri dishes with charred Eriogonum seeds at the soil surface and at $2 \mathrm{~cm}$ depth were compared using a linear model analysis (Proc CATMOD in SAS) [51].

2.2. Laboratory Experiments. Seeds of Eriogonum and Garberia were observed for germination after being exposed to a
TABLE 1: Weather conditions and fire characteristics for Florida sand pine scrub fires at Ocala National Forest and Archbold Biological Station during May 1993.

\begin{tabular}{lcc}
\hline & Ocala & Archbold \\
\hline Date of fire & May 10, 1993 & May 25, 1993 \\
Time of measurements & $1150-1205$ & $1259-1305$ \\
Air temperature & $28^{\circ} \mathrm{C}$ & $29^{\circ} \mathrm{C}$ \\
Relative humidity & $46 \%$ & $52 \%$ \\
Wind speed & $0.89 \mathrm{~m} / \mathrm{s}$ & $0.54 \mathrm{~m} / \mathrm{s}$ \\
Wind direction & $\mathrm{SE}$ & $\mathrm{SE}$ \\
Flame length & $3-5 \mathrm{~m}$ & $6-15 \mathrm{~m}$ \\
Rate of spread & $12 \mathrm{~m} / \mathrm{min}$ & $12 \mathrm{~m} / \mathrm{min}$ \\
\hline
\end{tabular}

control temperature $\left(25^{\circ} \mathrm{C}\right)$ and elevated temperatures and durations representative of those sustained at the soil surface and at $2 \mathrm{~cm}$ depth during the experimental fires. Elevated temperatures used were $100^{\circ} \mathrm{C}$ (commonly sustained at the soil surface for 4-6 minutes, but usually not reached at $2 \mathrm{~cm}$ depth) and $60^{\circ} \mathrm{C}$ (commonly sustained at $2 \mathrm{~cm}$ depth for 4 to $>91$ minutes).

Experiments were conducted from December 8-17, 1993, and from December 14, 1995 to January 7, 1996 for Eriogonum and Garberia seeds, respectively. Separate experiments, using 160 seeds in each, were conducted for each species and for each elevated temperature. Half of the seeds were placed in a drying oven and exposed to the elevated temperature for five minutes or 30 minutes in the experiments using $100^{\circ} \mathrm{C}$ and $60^{\circ} \mathrm{C}$, respectively. The remaining seeds in each experiment were kept at room temperature. Then seeds were placed on moist filter paper in petri dishes and observed for germination. Seed germination responses were compared between $25^{\circ} \mathrm{C}$ and $100^{\circ} \mathrm{C}$ treatments using Fisher exact tests [48]; $t$-tests were used to compare germination responses between $25^{\circ} \mathrm{C}$ and $60^{\circ} \mathrm{C}$ treatments.

To determine times required to melt temperaturesensitive paints on petri dishes, trials were conducted in which a petri dish painted with a temperature-sensitive paint was placed in a muffle furnace (Thermolyne, Sybron Corporation) with the door open, and timed until the paint melted. A minimum of five trials was conducted for each of 13 paints, with manufacturer-specified melting temperatures ranging from $37.8^{\circ} \mathrm{C}$ to $704.4^{\circ} \mathrm{C}$. After five trials, if the coefficient of variation was $>0.25$, additional trials were conducted. Up to 14 trials were conducted to record times required to melt paints with melting temperatures between $50^{\circ} \mathrm{C}$ and $125^{\circ} \mathrm{C}$, the temperature range likely relevant to seed survival versus mortality during fires.

\section{Results}

3.1. Field Experiments. Weather conditions and fire characteristics were similar for the two fires, but flame lengths in the Archbold fire were greater than those in the Ocala fire (Table 1). Although soil temperatures quantified with thermocouples and their temporal patterns varied widely 
TABLE 2: ANOVA of the effects of soil depth and microsite on maximum temperatures recorded during a controlled burn in sand pine scrub at Ocala National Forest, Florida. Temperatures were recorded with copper-constantan thermocouples placed at the soil surface and at $2 \mathrm{~cm}$ depth, and in open and vegetated microsites. Data were rank-transformed prior to the ANOVA.

\begin{tabular}{lcccc}
\hline Source & SS & $d f$ & $F$ ratio & $P$ \\
\hline Depth & 182.3 & 1 & 19.5 & $P<.005$ \\
Microsite & 25.0 & 1 & 2.7 & $P>.10$ \\
Depth $\times$ microsite & 20.3 & 1 & 2.2 & $P>.10$ \\
Error & 112.5 & 12 & & \\
\hline
\end{tabular}

TABle 3: ANOVA of the effects of soil depth and microsite on maximum temperatures recorded during a controlled burn in sand pine scrub at Archbold Biological Station, Florida. Temperatures were recorded with copper-constantan thermocouples placed at the soil surface and at $2 \mathrm{~cm}$ depth, and in open and vegetated microsites. Data were rank-transformed prior to the ANOVA.

\begin{tabular}{lcccc}
\hline Source & SS & $d f$ & $F$ ratio & $P$ \\
\hline Depth & 121.0 & 1 & 11.2 & $.005<P<.01$ \\
Microsite & 64.0 & 1 & 5.9 & $.025<P<.05$ \\
Depth $\times$ microsite & 25.0 & 1 & 2.3 & $P>.10$ \\
Error & 130.0 & 12 & & \\
\hline
\end{tabular}

TABle 4: Temperature durations of copper-constantan thermocouples placed at the soil surface and at $2 \mathrm{~cm}$ depth in the soil. Temperatures were quantified during prescribed fires conducted during May 1993 at Ocala National Forest and Archbold Biological Station, Florida. Temperature duration was defined as length of time that $(0.75 \times$ maximum thermocouple temperature $)$ was maintained or exceeded.

\begin{tabular}{lcl}
\hline Site & $\begin{array}{l}\text { Depth in soil } \\
(\mathrm{cm})(n=4)\end{array}$ & $\begin{array}{l}\text { Temperature duration }(\mathrm{s}) \\
(\text { median }(\text { range }))\end{array}$ \\
\hline Archbold & 0 & $105(20->3260)$ \\
\multirow{2}{*}{ Ocala } & 2 & $2020(160->3250)^{(\mathrm{a})}$ \\
& 0 & $80(65-1555)$ \\
& 2 & $2918(675->4625)^{(\mathrm{a})}$ \\
\hline
\end{tabular}

(a) Separate Kolmogorov-Smirnov tests were conducted for Archbold $(P=$ $.05)$ and Ocala $(P<.01)$ sites to test for difference in temperature durations with depth in soil.

both within and between microsite treatment combinations during both fires (Figures 1, 2, 3, and 4), temperatures were higher at the soil surface than at $2 \mathrm{~cm}$ depth as expected (Ocala: $F_{1,12}=19.5, P<.005$; Archbold: $F_{1,12}=11.2$, $.005<P<.01$ ), (Tables 2 and 3 ). Temperatures at the soil surface reached maxima of $628.8^{\circ} \mathrm{C}$ and $621.7^{\circ} \mathrm{C}$ during the Ocala and Archbold fires, respectively; in contrast, maximum temperatures at $2 \mathrm{~cm}$ depth were less than half those at the surface (Figures 1-4). The higher temperatures at the soil surface also had shorter durations than temperatures at $2 \mathrm{~cm}$ depth (Kolmogorov-Smirnov test; Ocala: $P<.01$; Archbold: $P=.05)$ (Table 4).

Temperatures in vegetated versus open microsites differed from predicted patterns, however. Although temperatures during the Ocala fire tended to be higher in vegetated

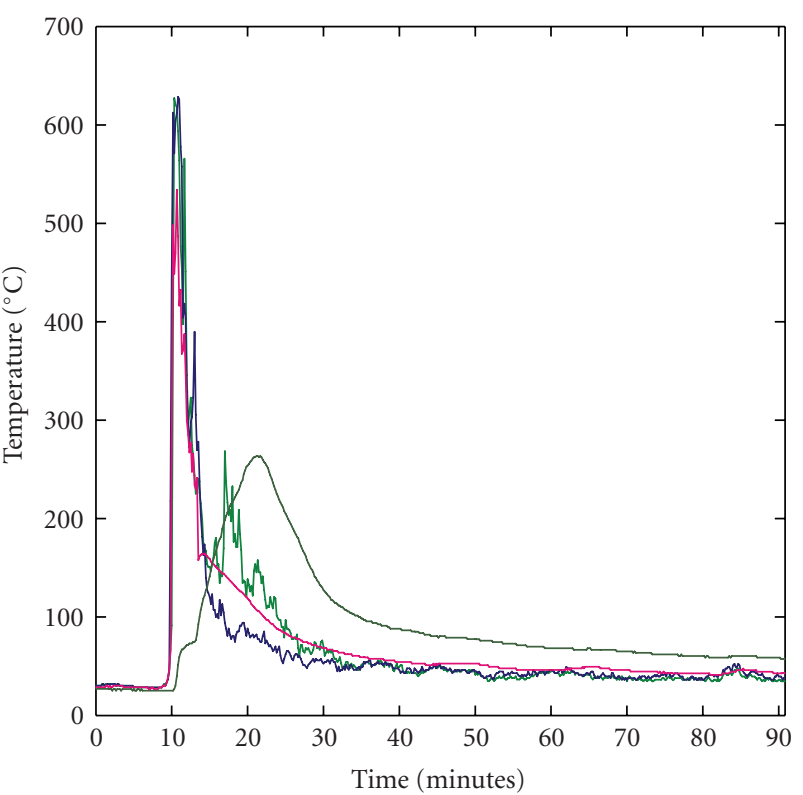

(a)

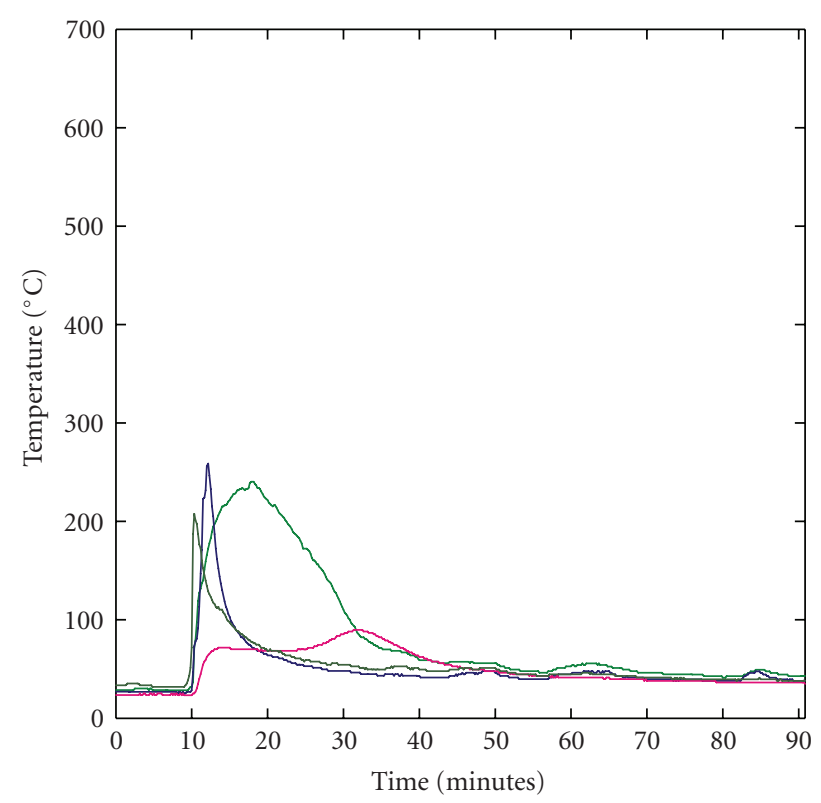

(b)

FIGURE 1: Soil temperatures at the soil surface during a prescribed sand pine scrub fire at Ocala National Forest, Florida on May 10, 1993. Temperatures were recorded with copper-constantan thermocouples placed in vegetated (a) and open (b) microsites. Each microsite location was replicated four times.

than in open microsites, a large range of temperatures within microsites resulted in no statistically significant difference in temperatures between microsites (Table 2). Temperatures during the Archbold fire were higher in open microsites than in vegetated microsites $\left(F_{1,12}=5.9, .025<P<.05\right.$; Table 3$)$, in contrast to the expected trend.

As with thermocouple-quantified temperatures, patterns of melted paints on petri dishes at the Archbold site showed 


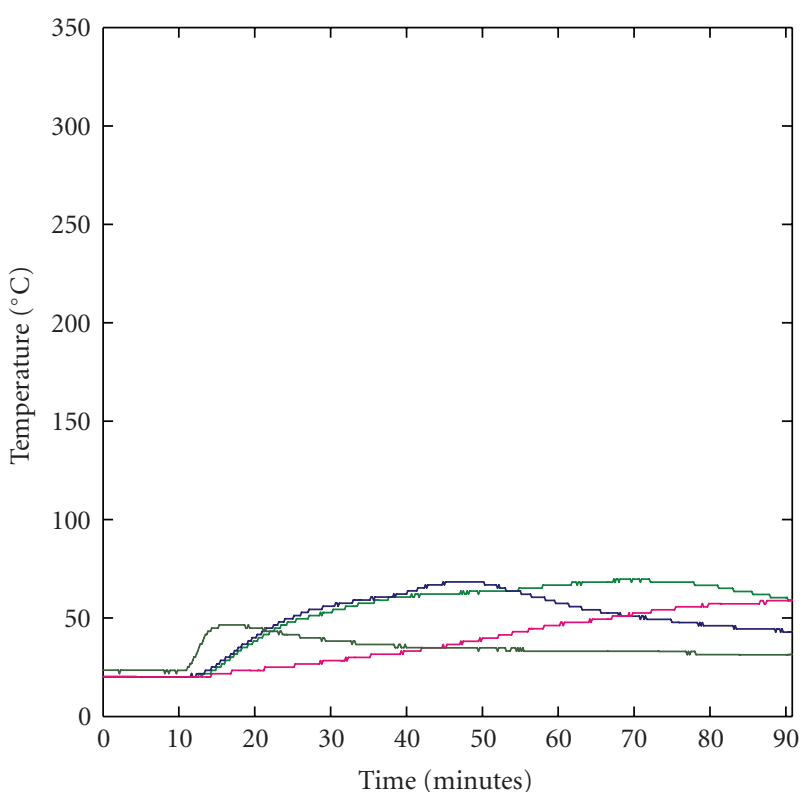

(a)

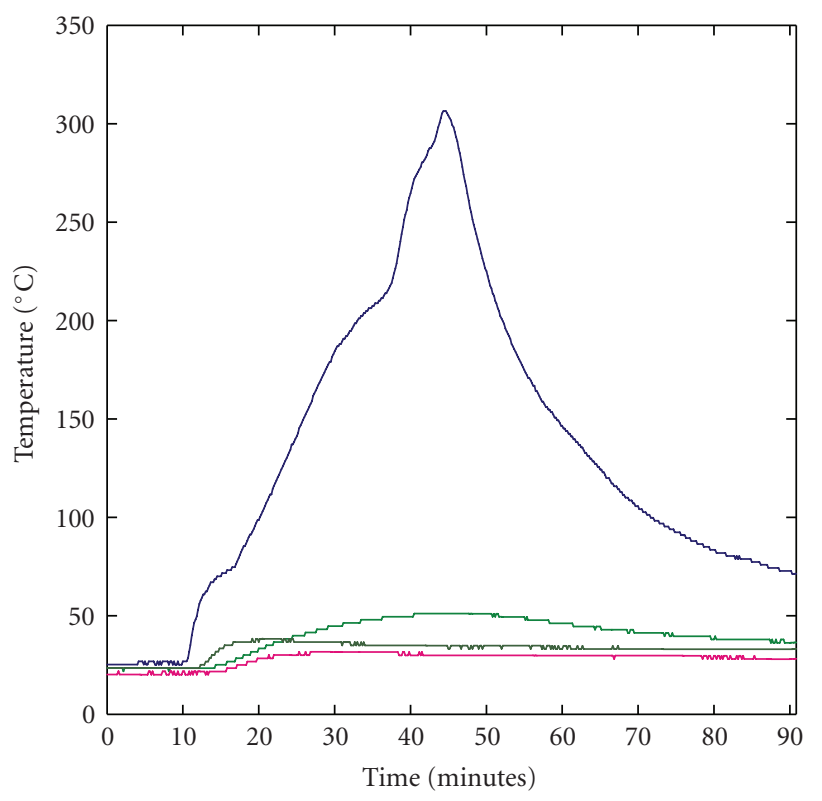

(b)

FIgURE 2: Soil temperatures at $2 \mathrm{~cm}$ depth during a prescribed sand pine scrub fire at Ocala National Forest, Florida on May 10, 1993. Temperatures were recorded with copper-constantan thermocouples placed in vegetated (a) and open (b) microsites. Each microsite location was replicated four times.

that maximum soil temperatures were higher at the surface than at $2 \mathrm{~cm}$ depth $\left(\chi^{2}=33.6, P<.001\right)$. Maximum temperatures of petri dishes placed at the soil surface varied widely. Most temperatures ranged from $93^{\circ} \mathrm{C}$ to $315^{\circ} \mathrm{C}$, but 4 of 24 surface petri dishes reached temperatures $>343^{\circ} \mathrm{C}$, while 2 surface/open petri dish temperatures were $<37.8^{\circ} \mathrm{C}$ (Figure 5). In contrast, maximum temperatures of petri dishes placed at $2 \mathrm{~cm}$ depth were more similar; only 1 of 24

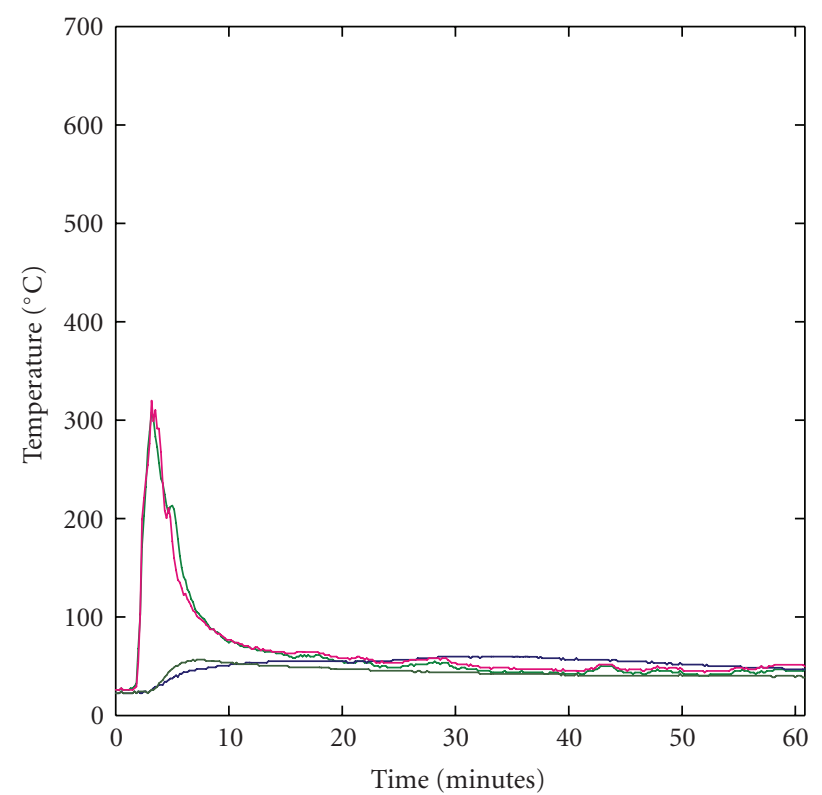

(a)

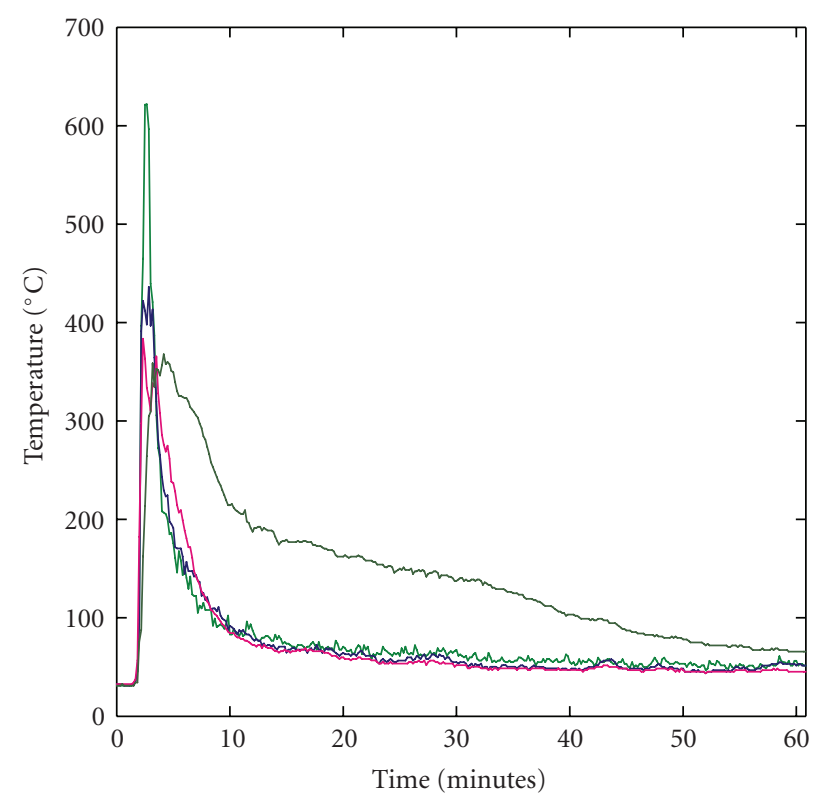

(b)

FIGURE 3: Soil temperatures at the soil surface during a prescribed sand pine scrub fire at Archbold Biological Station, Florida on May 25, 1993. Temperatures were recorded with copper-constantan thermocouples placed in vegetated (a) and open (b) microsites. Each microsite location was replicated four times.

petri dishes placed at $2 \mathrm{~cm}$ depth exceeded $100^{\circ} \mathrm{C}$ (Figure 5). Although differences between temperatures of petri dishes in open versus vegetated microsites were not tested statistically due to small sample sizes, temperatures appeared similar among microsites (Figure 5). Comparison of thermocouple maximum temperatures with maximum temperatures of adjacent petri dishes showed that temperatures quantified via the two methods differed $(t=25.0, .02<P<.05)$ 


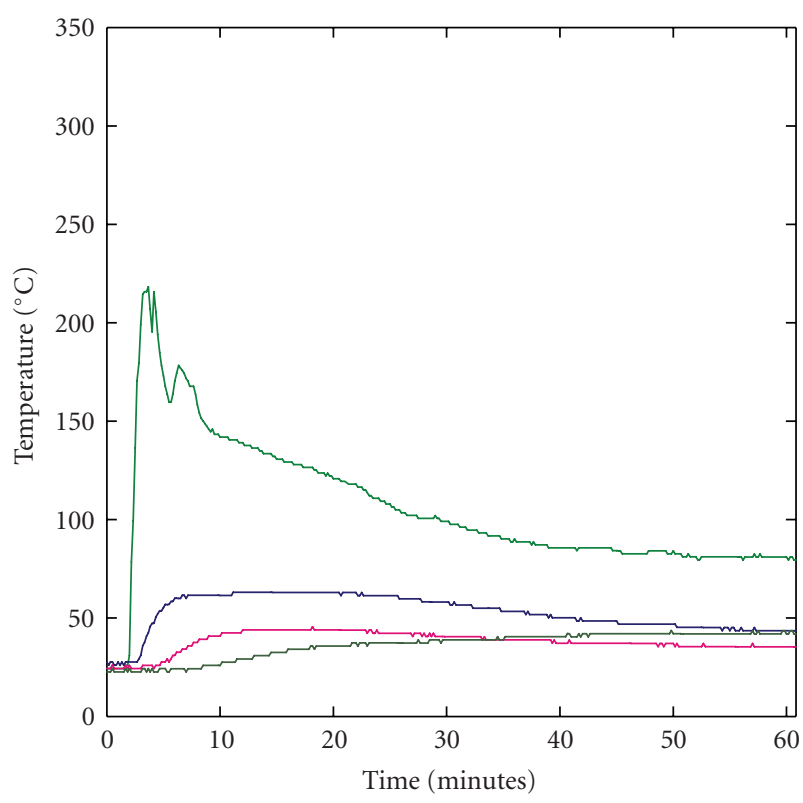

(a)

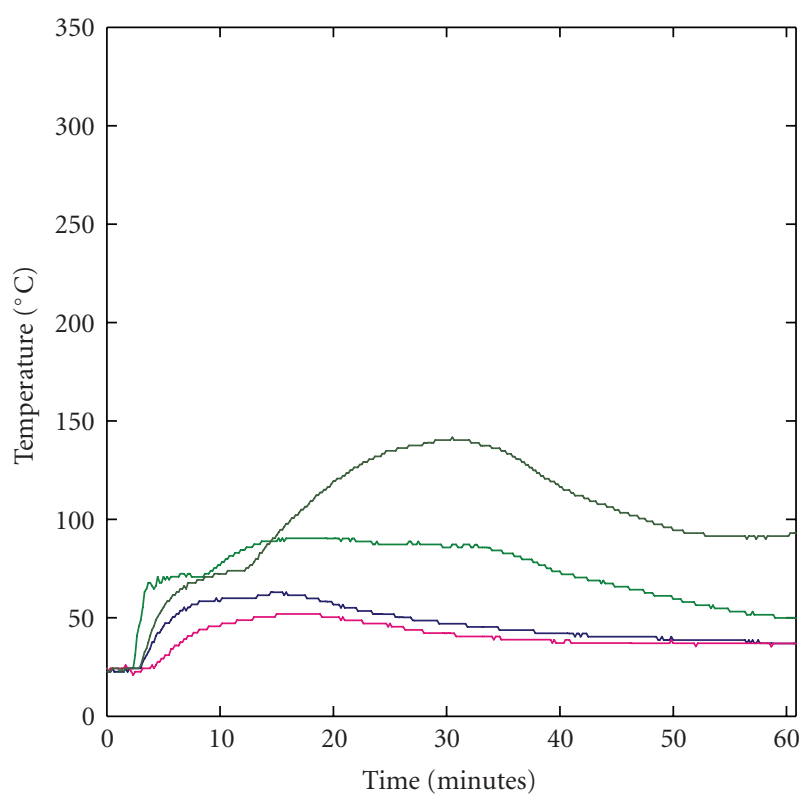

(b)

FIgURE 4: Soil temperatures at $2 \mathrm{~cm}$ depth during a prescribed sand pine scrub fire at Archbold Biological Station, Florida on May 25, 1993. Temperatures were recorded with copper-constantan thermocouples placed in vegetated (a) and open (b) microsites. Each microsite location was replicated four times.

(Table 5), presumably due to time required to melt paints on petri dishes (Figure 6).

Most non-charred Eriogonum seeds recovered after both fires were from petri dishes placed at $2 \mathrm{~cm}$ depth $(\chi=43.95$, $P<.001)$. Of a total of 34 petri dishes recovered from the soil surface after the fires, only one dish contained non-charred seeds. Numbers of petri dishes with charred seeds did not appear to differ between open and vegetated microsites,
TABLe 5: Maximum temperatures at $0 \mathrm{~cm}$ and $2 \mathrm{~cm}$ soil depth, and in open and vegetated microsites, during a prescribed fire in sand pine scrub at Archbold Biological Station, Florida. Temperatures were quantified with copper-constantan thermocouples and with temperature-sensitive paints placed on adjacent glass petri dishes.

\begin{tabular}{lccc}
\hline \multirow{2}{*}{ Depth } & \multirow{2}{*}{ Microsite } & \multicolumn{2}{c}{ Maximum Temperature } \\
& & Thermocouple & Paint $^{(\mathrm{a})}$ \\
\hline $0 \mathrm{~cm}$ & open & 621.7 & 163.7 \\
$0 \mathrm{~cm}$ & open & 436.2 & 107.2 \\
$0 \mathrm{~cm}$ & open & 383.5 & 289.8 \\
$0 \mathrm{~cm}$ & open & 367.8 & $<37.8$ \\
$0 \mathrm{~cm}$ & vegetated & 308.1 & 260.0 \\
$0 \mathrm{~cm}$ & vegetated & 59.8 & 287.8 \\
$0 \mathrm{~cm}$ & vegetated & 319.8 & 232.2 \\
$0 \mathrm{~cm}$ & vegetated & 56.9 & 162.8 \\
$2 \mathrm{~cm}$ & open & 63.0 & $<37.8$ \\
$2 \mathrm{~cm}$ & open & 90.4 & $<37.8$ \\
$2 \mathrm{~cm}$ & open & 52.0 & $<37.8$ \\
$2 \mathrm{~cm}$ & open & 141.7 & $<37.8$ \\
$2 \mathrm{~cm}$ & vegetated & 218.3 & $<37.8$ \\
$2 \mathrm{~cm}$ & vegetated & 63.0 & $<37.8$ \\
$2 \mathrm{~cm}$ & vegetated & 45.6 & $<37.8$ \\
$2 \mathrm{~cm}$ & vegetated & 43.6 & $<37.8$ \\
\hline
\end{tabular}

(a) Temperatures represent the manufacturer-specified melting temperatures of the paints that melted.

TABle 6: Number of petri dishes from which charred Eriogonum floridanum seeds were recovered after controlled burns in sand pine scrub at Archbold Biological Station and at Ocala National Forest, Florida, versus number of petri dishes from which all seeds were recovered non-charred; and total number of non-charred seeds recovered. Petri dishes were placed at $0 \mathrm{~cm}$ and $2 \mathrm{~cm}$ depth in the soil, and in open and vegetated (from $0-2 \mathrm{~m}$ vegetation height) microsites. Each petri dish contained ten seeds.

\begin{tabular}{llll}
\hline $\begin{array}{l}\text { Soil } \\
\text { depth/microsite }\end{array}$ & $\begin{array}{l}\text { Petri dishes } \\
\text { with charred } \\
\text { seeds }\end{array}$ & $\begin{array}{l}\text { Petri dishes } \\
\text { without charred } \\
\text { seeds }^{(a)}\end{array}$ & $\begin{array}{l}\text { Total non- } \\
\text { charred } \\
\text { seeds }\end{array}$ \\
\hline $0 \mathrm{~cm} /$ open & 17 & 0 & 0 \\
$0 \mathrm{~cm} /$ vegetated & 16 & 1 & 10 \\
$2 \mathrm{~cm} /$ open & 3 & 14 & 154 \\
$2 \mathrm{~cm} /$ vegetated & 3 & 14 & 156 \\
\hline
\end{tabular}

(a) More petri dishes with non-charred seeds were recovered from $2 \mathrm{~cm}$ depth $\left(\chi^{2}=43.95, P<.001\right)$.

although differences were not tested statistically due to small sample sizes (Table 6).

No seeds germinated during trials using non-charred seeds recovered after the fires. Tetrazolium tests on seeds that were collected at the same time as seeds used in the experimental fires indicated that viability was $34 \pm 4 \%$.

3.2. Laboratory Experiments. In both Eriogonum and Garberia experiments $100^{\circ} \mathrm{C}$ was lethal to seeds; no seeds exposed 


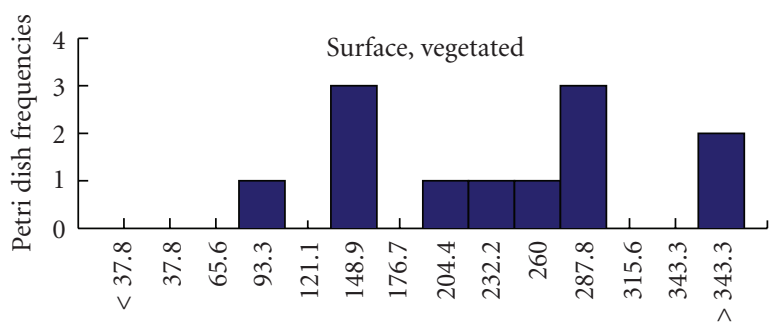

Temperature intervals $\left({ }^{\circ} \mathrm{C}\right)$

(a)

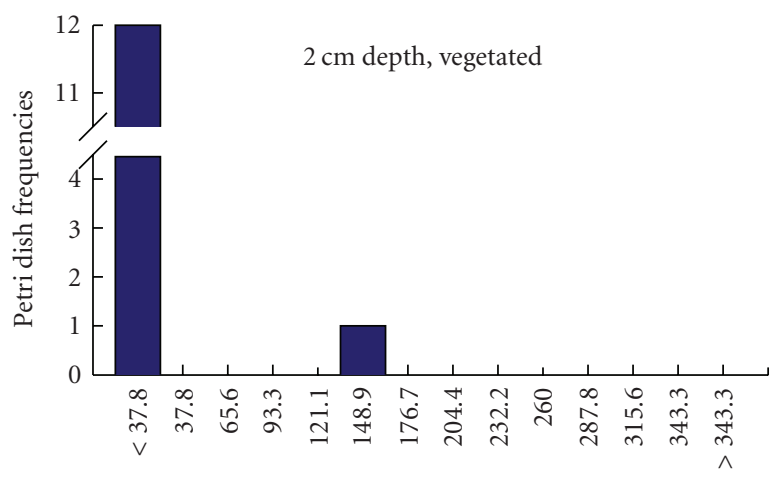

Temperature intervals $\left({ }^{\circ} \mathrm{C}\right)$

(c)

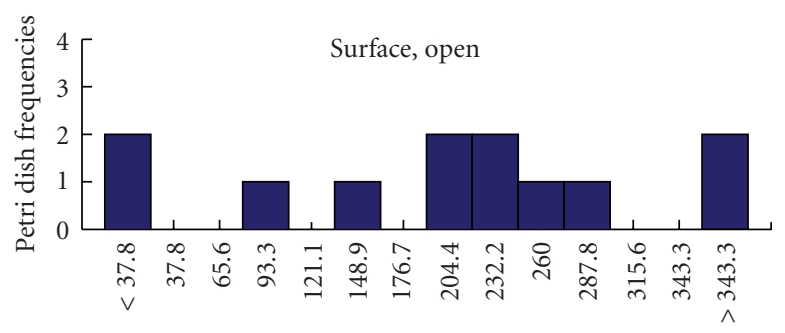

Temperature intervals $\left({ }^{\circ} \mathrm{C}\right)$

(b)

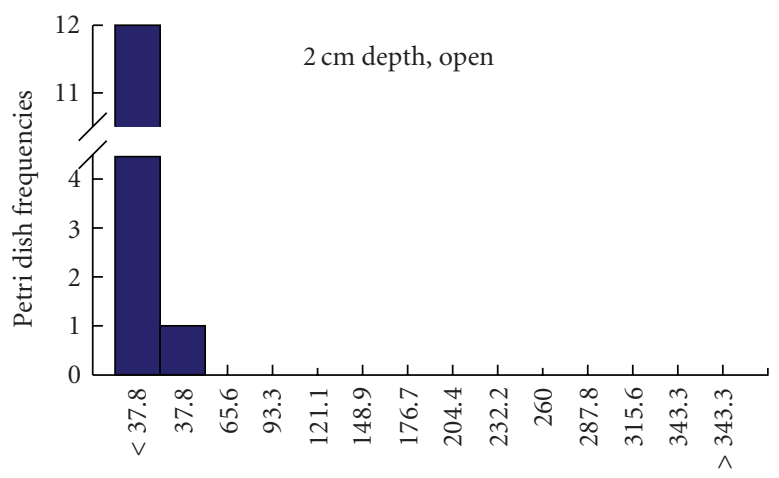

Temperature intervals $\left({ }^{\circ} \mathrm{C}\right)$

(d)

Figure 5: Frequency distributions of maximum petri dish temperatures during a prescribed sand pine scrub fire at Archbold Biological Station, Florida on May 25, 1993. Temperatures were quantified with temperature-sensitive paints on the petri dishes; temperature intervals for the frequency distributions represent melting points of the paints. Petri dishes were placed at the soil surface in vegetated (a) and open (b) microsites, and at $2 \mathrm{~cm}$ depth in vegetated (c) and open (d) microsites; each depth-microsite combination was replicated 12 times.

TABle 7: Number of petri dishes from which Eriogonum floridanum (Polygonaceae) and Garberia heterophylla (Asteraceae) seeds germinated after being exposed to $100^{\circ} \mathrm{C}$ or $25^{\circ} \mathrm{C}$ for 5 minutes. Germination trials were conducted from December 8-17, 1993, and from December 14, 1995 to January 2, 1996 for Eriogonum and Garberia, respectively.

\begin{tabular}{lcl}
\hline Seed species & Temperature $\left({ }^{\circ} \mathrm{C}\right)$ & $\begin{array}{l}\text { Number of petri } \\
\operatorname{dishes~}^{(\mathrm{a})}(n=4)\end{array}$ \\
\hline Eriogonum & 25 & 4 \\
Garberia & 100 & $0^{(\mathrm{b})}$ \\
& 25 & 4 \\
\hline
\end{tabular}

(a) Each petri dish contained 20 seeds.

(b) Fisher exact test showed a reduction in germination $(P=.0143)$.

to $100^{\circ} \mathrm{C}$ for five minutes germinated, while seeds exposed to room temperature germinated in all petri dishes (Fisher exact test, $P=.0143$ for both species, Table 7). Seeds of both species also behaved similarly when exposed to $60^{\circ} \mathrm{C}$ for 30 minutes; seeds germinated from all petri dishes in both experiments, with no differences in numbers germinating between seeds exposed to $60^{\circ} \mathrm{C}$ and seeds exposed to room temperature (Eriogonum: $t=1.27, P=.25$; Garberia: $t=$ 0.397, .5<P<.9; Table 8).
TABle 8: Number (mean \pm S.E.) of Eriogonum floridanum (Polygonaceae) and Garberia heterophylla (Asteraceae) seeds that germinated after being exposed to $60^{\circ} \mathrm{C}$ or $25^{\circ} \mathrm{C}$ for 30 minutes. Germination trials were conducted from December 8-17, 1993, and from December 30, 1995 to January 7, 1996 for Eriogonum and Garberia, respectively. Identical superscripts within the same species indicate no difference in germination between temperature treatments $(t$-test, $P>.05)$.

\begin{tabular}{lcc}
\hline Seed species & $\begin{array}{c}\text { Temperature } \\
\left({ }^{\circ} \mathrm{C}\right)^{\dagger}\end{array}$ & Germinated seeds (mean \pm S.E. $)$ \\
\hline Eriogonum & 25 & $15.0 \pm 1.6^{(\mathrm{a})}$ \\
Garberia & 60 & $11.5 \pm 2.3^{(\mathrm{a})}$ \\
& 25 & $19.0 \pm 0.4^{(\mathrm{a})}$ \\
& 60 & $19.3 \pm 0.5^{(\mathrm{a})}$ \\
\hline
\end{tabular}

${ }^{\dagger} n=4$ petri dishes, each with 20 seeds.

\section{Discussion}

4.1. Soil Temperatures during Fires. Depth in the soil has a strong influence on magnitude and variability of temperatures during Florida sand pine scrub fires, and thus influences seed survival during fires. As expected, maximum temperatures at the soil surface were higher and peak temperature durations were shorter than at $2 \mathrm{~cm}$ depth. Less predictable, however, were (1) effects of microsites at the soil surface on maximum temperatures; and (2) detailed 


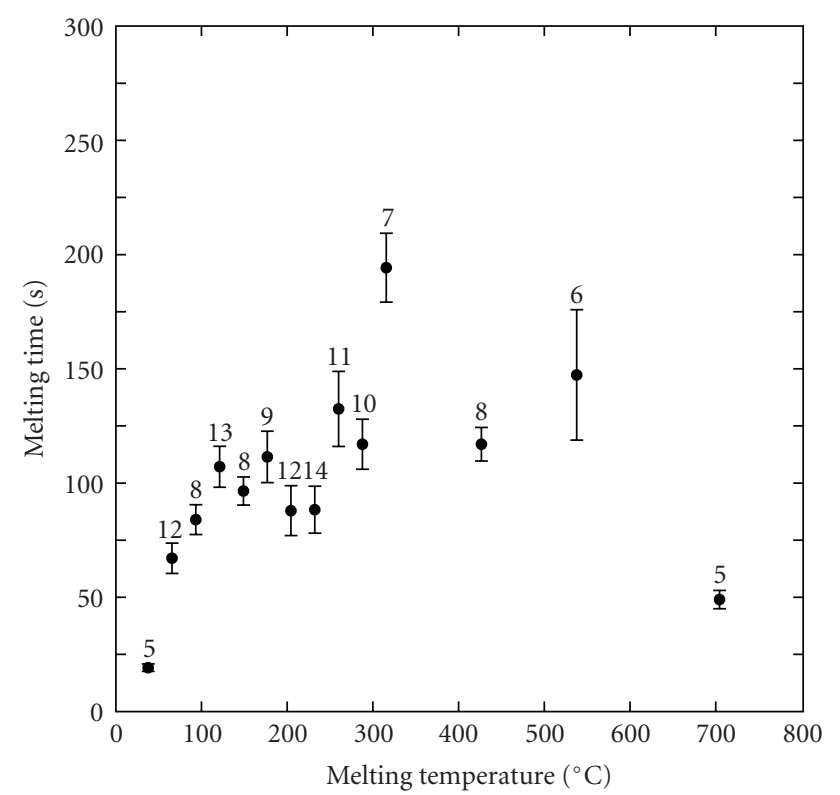

Figure 6: Melting times (mean \pm S.E.) of temperature-sensitive paints (Tempilaq, Tempil Division, Big Three Industries, Inc.) on glass petri dishes. The number above each symbol represents the number of melting trials conducted for that paint. In each trial a petri dish was placed in a muffle furnace set at the melting temperature of the paint on the dish, and melting time was quantified.

spatial patterns of temperatures at the soil surface, and their implications for seed survival.

The effect of microsites on soil temperatures was different from that predicted, and was different between the two fires. Differences in overstory pine species and resulting litter characteristics between the sites contributed to the different microsite effects. Sand pine, the only tree species at Ocala, produces sparse litter consisting of short needles, but south Florida slash pine has much longer and more flammable needles than sand pine, and produces more litter. Because south Florida slash pine was present only at Archbold, different types and amounts of pine litter had accumulated in open microsites at the two sites; litter in vegetated microsites consisted primarily of sclerophyllous leaves with comparatively low flammability.

During the Ocala fire, a high variance in temperatures within microsites precluded detection of a microsite effect. During the Archbold fire a microsite effect was detected, but the pattern of temperatures between open and vegetated microsites was the reverse of the expected pattern. Higher maximum temperatures in open microsites were probably due to the well-aerated, relatively flammable slash pine litter in open microsites burning more completely and at higher temperatures than the more compacted, less flammable oak and hickory litter in vegetated microsites [50]. As reported in other studies $[12,14,15]$, patterns of soil temperatures during fires appear to be related more directly to litter (i.e., fuel) type and amount than to microsites defined in this study.
Not only was the effect of microsites on soil temperature unpredictable, but temperatures at the soil surface in general were variable when compared to temperatures at $2 \mathrm{~cm}$ depth. Soil surface temperatures, in addition to having greater variation among experimental locations than at $2 \mathrm{~cm}$ depth, varied widely both in time and in space within experimental locations, as demonstrated by temperatures recorded with thermocouples and with temperaturesensitive paints. Temperatures recorded by thermocouples at the soil surface generally increased to extremely high, brief maxima, thereby producing many within-location combinations of temperatures and temperature durations. As a consequence of this high variation in temperatures over time, temperature-sensitive paints on petri dishes usually underestimated maximum temperatures of adjacent thermocouples at the soil surface. The maximum temperatures recorded by temperature-sensitive paints apparently were the highest temperatures that persisted long enough to melt the corresponding paints. As might be predicted by the variation in patterns of thermocouple temperatures versus time, differences between maximum temperatures of petri dishes and adjacent thermocouples varied widely.

Differences between petri dish and adjacent thermocouple temperatures at Archbold also indicated that soil temperatures varied spatially within experimental locations. Because maximum temperatures recorded by temperaturesensitive paints often differed from those expected based on temperature patterns of adjacent thermocouples (Table 4 , Figures 3 and 4), temperatures and temperature durations must have varied over a very small spatial scale.

4.2. Seed Survival during Fires. Because virtually all maximum temperatures at the soil surface were $>100^{\circ} \mathrm{C}$ and lethal to Eriogonum and Garberia seeds, much of the variation in soil surface temperatures during fires was irrelevant to seed survival for these species. Such extremely variable but high temperatures also should be lethal to most other species of seeds; in other studies, even seeds for which germination increased after exposure to high temperatures were usually killed by temperatures between $120-150^{\circ} \mathrm{C}$ [32] . Nevertheless, a fraction of seeds at the soil surface may survive fires in sand pine scrub, because Eriogonum seeds in one petri dish at the soil surface remained non-charred, and soil surface temperatures presumably were heterogeneous at a very small scale.

Seed survival is more likely and more predictable at $2 \mathrm{~cm}$ depth in the soil, because soil temperatures during fires were relatively low, and varied little from site to site. Although higher proportions of seeds should survive through fire at this depth in the soil, some seed mortality must occur, because lethal temperatures were occasionally reached. Surprisingly, in this study all Eriogonum seeds recovered after the Archbold fire from petri dishes placed at the surface and at $2 \mathrm{~cm}$ depth failed to germinate, even though seeds subjected to temperatures lower than $100^{\circ} \mathrm{C}$ in the laboratory germinated. Perhaps an unanticipated factor, possibly related to the glass petri dishes, prevented germination after the fire. 
For species that rely on recruitment from seeds that survive through fire, a tradeoff exists between higher probability of survival and increasing difficulty of seedling emergence with increasing depth in the soil. Seedlings from larger seeds should emerge from $2 \mathrm{~cm}$ depth with little difficulty, as has been demonstrated for several legume species with seed masses near $30 \mathrm{mg}[9,13,32]$. Eriogonum and Garberia seeds, however, are much smaller, having an average mass of $3.7 \pm 0.1 \mathrm{mg}$. Their seeds may be incapable of germination and seedling emergence from $2 \mathrm{~cm}$ depth, especially because litter apparently acted as a mechanical barrier to Eriogonum seedling emergence in another experiment $[52,53]$.

The extremely limited capacities for Eriogonum and Garberia seed survival through fires are consistent with postfire recruitment characteristics for these species. In a concurrent study of seedling recruitment following the experimental fires, Eriogonum and Garberia seedlings germinated from seeds produced after the fires by resprouting adults. Seeds of some species quantified as seedlings after the fires (e.g., Calamintha ashei, Lupinus diffusus, Tephrosia chrysophylla), however, presumably germinated after surviving the fires, as adults of the species were killed by the fires and seeds had no obvious long-distance dispersal mechanisms [51]. Although seed germination characteristics for these adult-killed species are unknown, seeds probably were capable of germinating after exposure to elevated temperatures (i.e., $-60-100^{\circ} \mathrm{C}$ ). Seeds germinated either at the soil surface in microsites that failed to reach lethal temperatures, or at depths beneath the soil surface from which seedlings could emerge.

This study not only showed that patterns of temperatures differ between the soil surface and $2 \mathrm{~cm}$ depth, but also demonstrated differences in relative strengths and weaknesses of two temperature quantification methods. Temperature-sensitive paints on petri dishes were much less precise than thermocouples in quantifying maximum temperatures; therefore, results from temperature-sensitive paints were reliable only at $2 \mathrm{~cm}$ depth, where temperature durations were long. Nevertheless, temperature-sensitive paints are adequate for documenting large differences in temperatures between depths in the soil, and for recording maximum temperatures beneath the soil surface, where relatively large proportions of seeds should survive fires.

In addition to maximum temperatures, temperature duration influences seed survival through fires. Since (1) variation in temperature duration and spatial variation in maximum temperatures at the soil surface are potentially relevant to seed survival and (2) thermocouples can quantify temperature duration and complex spatial patterns in temperatures, thermocouples should be used in studies of temperatures relevant to seed survival during fires to quantify temperature patterns at the soil surface.

Results from this study suggest that small-scale spatial variation in temperature exists at the soil surface during fires, and that low-temperature patches are essential for seed survival on the soil surface. Additional studies are needed to document small-scale patterns of temperatures, temperature durations, and seed survival at the soil surface during fires. Seed survival through fire and germination after fire, however, are only a small part of the process of postfire recruitment. Future research on topics such as effects of postfire microsite conditions on seedling establishment, and the relevance of postfire microsite conditions to the evolution of seed germination characteristics, will contribute to a comprehensive characterization of postfire recruitment.

\section{References}

[1] L. J. Lyon and P. F. Stickney, "Early vegetal succession following large northern Rocky Mountain wildfires," in Proceedings of the Montana Tall Timbers Fire Ecology Conference and Fire and Land Management Symposium, pp. 355-375, Tall Timbers Research Station, Tallahassee, Fla, USA, 1976.

[2] V. T. Parker and V. R. Kelly, "Seed banks in Californian chaparral and other Mediterranean climate shrublands," in Ecology of Soil Seed Banks, pp. 231-255, Academic Press, San Diego, Calif, USA, 1989.

[3] F. Heyward, "Soil temperatures during forest fires in the longleaf pine region," Journal of Forestry, vol. 36, pp. 478-491, 1938.

[4] N. C. Beadle, "Soil temperatures during forest fires and their effect on the survival of vegetation," Journal of Ecology, vol. 28, pp. 180-192, 1940.

[5] E. Whittaker, “Temperatures in heath fires," Journal of Ecology, vol. 49, pp. 709-715, 1961.

[6] G. Floyd, "Effect of fire upon weed seeds in the wet sclerophyll forests of northern New South Wales," Australian Journal of Botany, vol. 14, pp. 233-256, 1966.

[7] J. Kayll, "Some characteristics of heath fires in north-east Scotland," Journal of Applied Ecology, vol. 3, pp. 29-40, 1966.

[8] D. R. Scotter, "Soil temperatures under grass fires," Australian Journal of Soil Research, vol. 8, pp. 272-279, 1970.

[9] S. R. Shea, J. McCormick, and C. C. Portlock, "The effect of fires on regeneration of leguminous species in the northern jarrah (Eucalyptus marginata Sm) forest of Western Australia," Australian Journal of Ecology, vol. 4, pp. 195-205, 1979.

[10] M. Gill and R. H. Groves, "Fire regimes in heathlands and their plant-ecological effects," in Heathlands and Related Shrublands, R. L. Specht, Ed., pp. 61-84, Elsevier Scientific, New York, NY, USA, 1981.

[11] R. J. Hobbs, J. E. P. Currall, and C. H. Gimingham, "The use of 'thermocolor' pyrometers in the study of heath fire behaviour," Journal of Ecology, vol. 72, no. 1, pp. 241-250, 1984.

[12] D. T. Patten and G. H. Cave, "Fire temperatures and physical characteristics of a controlled burn in the upper Sonoran desert," Journal of Range Management, vol. 37, pp. 277-280, 1984.

[13] T. D. Auld, "Population dynamics of the shrub Acacia suaveolens (Sm.) Willd.: fire and the transition to seedlings," Australian Journal of Ecology, vol. 11, no. 4, pp. 373-385, 1986.

[14] P. Stott, "The spatial pattern of dry season fires in the savanna forests of Thailand," Journal of Biogeography, vol. 13, no. 4, pp. 345-358, 1986.

[15] R. J. Hobbs and L. Atkins, "Spatial variability of experimental fires in south-west Western Australia," Australian Journal of Ecology, vol. 13, no. 3, pp. 295-299, 1988.

[16] M. R. Muñoz and E. R. Fuentes, "Does fire induce shrub germination in the Chilean matorral?" Oikos, vol. 56, no. 2, pp. 177-181, 1989.

[17] R. A. Bradstock, T. D. Auld, M. E. Ellis, and J. S. Cohn, "Soil temperatures during bushfires in semi-arid, mallee shrublands," Australian Journal of Ecology, vol. 17, no. 4, pp. 433-440, 1992. 
[18] A. C. Miranda, H. S. Miranda, I. de Fatima Oliveira Dias, and B. F. de Souza Dias, "Soil and air temperatures during prescribed cerrado fires in central Brazil," Journal of Tropical Ecology, vol. 9, no. 3, pp. 313-320, 1993.

[19] R. A. Bradstock and T. D. Auld, "Soil temperatures during experimental bushfires in relation to fire intensity: consequences for legume germination and fire management in south-eastern Australia," Journal of Applied Ecology, vol. 32, no. 1, pp. 76-84, 1995.

[20] D. C. Odion and F. W. Davis, "Fire, soil heating, and the formation of vegetation patterns in chaparral," Ecological Monographs, vol. 70, no. 1, pp. 149-169, 2000.

[21] M. L. Brooks, "Peak fire temperatures and effects on annual plants in the Mojave Desert," Ecological Applications, vol. 12, no. 4, pp. 1088-1102, 2002.

[22] B. Perez and J. M. Moreno, "Methods for quantifying fire severity in shrubland-fires," Plant Ecology, vol. 139, no. 1, pp. 91-101, 1998.

[23] D. K. Kennard, K. W. Outcalt, D. Jones, and J. J. O'Brien, "Comparing techniques for estimating flame temperatures of prescribed fires," Plant Ecology, vol. 1, no. 1, pp. 75-84, 2005.

[24] A. L. Wally, E. S. Menges, and C. W. Weekley, "Comparison of three devices for estimating fire temperatures in ecological studies," Applied Vegetation Science, vol. 9, no. 1, pp. 97-108, 2006.

[25] F. W. Went, G. Juhren, and M. C. Juhren, "Fire and biotic factors affecting germination," Ecology, vol. 33, pp. 351-364, 1952.

[26] E. C. Stone and G. Juhren, "Fire stimulated germinationeffect of burning on germination of brush seed investigated in physiological study of chamise," California Agriculture, vol. 7, pp. 13-14, 1953.

[27] E. B. Hadley, "Influence of temperature and other factors on Ceanothus megacarpus seed germination," Madroño, vol. 16, pp. 132-138, 1961.

[28] R. E. Martin, R. L. Miller, and C. T. Cushwa, "Germination response of legume seeds subjected to moist and dry heat," Ecology, vol. 56, pp. 1441-1445, 1975.

[29] J. E. Keeley, B. A. Morton, A. Pedrosa, and P. Trotter, "Role of allelopathy, heat and charred wood in the germination of chaparral herbs and suffrutescents," Journal of Ecology, vol. 73, no. 2, pp. 445-458, 1985.

[30] J. E. Keeley, "Role of fire in seed germination of woody taxa in California chaparral," Ecology, vol. 68, no. 2, pp. 434-443, 1987.

[31] S. C. Barro and M. Poth, "Seeding and sprouting Ceanothus species: their germination responses to heat," in Time Scales and Water Stress: Proceedings of the 5th International Conference on Mediterranean Ecosystems, F. di Castri, Ch. Floret, S. Rambal, and J. Roy, Eds., pp. 455-458, I.U.B.S., Paris, France, 1988.

[32] T. D. Auld and M. A. O'Connell, "Predicting patterns of postfire germination in 35 eastern Australian Fabaceae," Australian Journal of Ecology, vol. 16, pp. 53-70, 1991.

[33] J. E. Keeley, "Seed germination and life history syndromes in the California chaparral," Botanical Review, vol. 57, no. 2, pp. 81-116, 1991.

[34] J. Roy and L. Sonie, "Germination and population dynamics of Cistus species in relation to fire," Journal of Applied Ecology, vol. 29, no. 3, pp. 647-655, 1992.

[35] F. González-Rabanal, M. Casal, and L. Trabaud, "Effects of high temperatures, ash and seed position in the inflorescence on the germination of three Spanish grasses," Journal of Vegetation Science, vol. 5, no. 3, pp. 289-294, 1994.
[36] R. L. Myers, "Scrub and high pine," in Ecosystems of Florida, R. L. Myers and J. J. Ewel, Eds., pp. 150-193, University of Central Florida Press, Orlando, Fla, USA, 1990.

[37] R. E. Lopez and R. L. Holle, "The distribution of summertime lightning as a function of low-level wind flow in central Florida," Technical Memorandum ERL ESG-28, NOAA, 1987.

[38] A. F. Johnson and W. G. Abrahamson, "A note on the fire responses of species in rosemary scrubs on the southern Lake Wales ridge," Florida Scientist, vol. 53, pp. 138-143, 1990.

[39] E. S. Menges, "Habitat preferences and response to disturbance for Dicerandra frutescens, a Lake Wales Ridge (Florida) endemic plant," Bulletin of the Torrey Botanical Club, vol. 119, pp. 308-313, 1992.

[40] E. S. Menges and N. Kohfeldt, "Life history strategies of Florida scrub plants in relation to fire," Bulletin of the Torrey Botanical Club, vol. 122, pp. 282-297, 1995.

[41] W. G. Abrahamson and J. R. Abrahamson, "Effects of a lowintensity, winter fire on long-unburned Florida sand pine scrub," Natural Areas Journal, vol. 16, no. 3, pp. 171-183, 1996.

[42] M. E. Carrington, "Post-fire seedling establishment in Florida sand pine scrub," Journal of Vegetation Science, vol. 10, no. 3, pp. 403-412, 1999.

[43] D. C. Le Maitre and J. J. Midgley, "Plant reproductive ecology," in The Ecology of Fynbos: Nutrients, Fire and Diversity, R. M. Cowling, Ed., pp. 135-174, Oxford University Press, Cape Town, South Africa, 1992.

[44] A. F. Johnson, "Some demographic characteristics of the Florida rosemary Ceratiola ericoides Michx," American Midland Naturalist, vol. 108, no. 1, pp. 170-174, 1982.

[45] P. B. Thomas, E. C. Morris, and T. D. Auld, "Interactive effects of heat shock and smoke on germination of nine species forming soil seed banks within the Sydney region," Austral Ecology, vol. 28, no. 6, pp. 674-683, 2003.

[46] P. B. Thomas, E. C. Morris, and T. D. Auld, "Response surfaces for the combined effects of heat shock and smoke on germination of 16 species forming soil seed banks in southeast Australia," Austral Ecology, vol. 32, no. 6, pp. 605-616, 2007.

[47] M. E. Carrington, "Soil seed bank structure and composition in Florida sand pine scrub," American Midland Naturalist, vol. 137, no. 1, pp. 39-47, 1997.

[48] G. Lakon, "The topographical tetrazolium method for determining the germination capacity of seeds," Plant Physiology, vol. 24, pp. 389-394, 1949.

[49] SAS Institute Inc, SAS/STAT User's Guide: Release 6.03 Edition, SAS Institute Inc., Cary, NC, USA, 1988.

[50] S. Siegel and N. J. Castellan Jr., Nonparametric Statistics for the Behavioral Sciences, McGraw-Hill, New York, NY, USA, 1988.

[51] SAS Institute Inc., SAS/STAT ${ }^{\circledR} 9.1$ User's Guide, SAS Institute Inc., Cary, NC, USA, 2004.

[52] M. E. Carrington, Postfire recruitment in Florida sand pine scrub in comparison with California chaparral, Ph.D. dissertation, University of Florida, Gainesville, Fla, USA, 1996.

[53] W. J. Bond, M. Honig, and K. E. Maze, "Seed size and seedling emergence: an allometric relationship and some ecological implications," Oecologia, vol. 120, no. 1, pp. 132-136, 1999. 

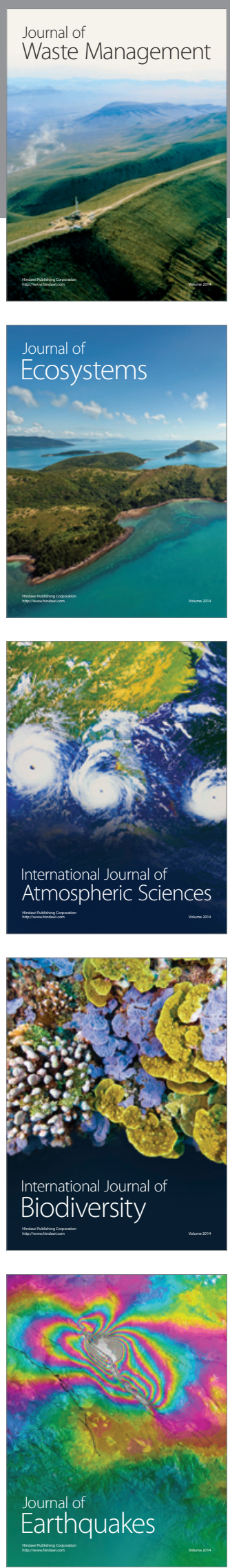
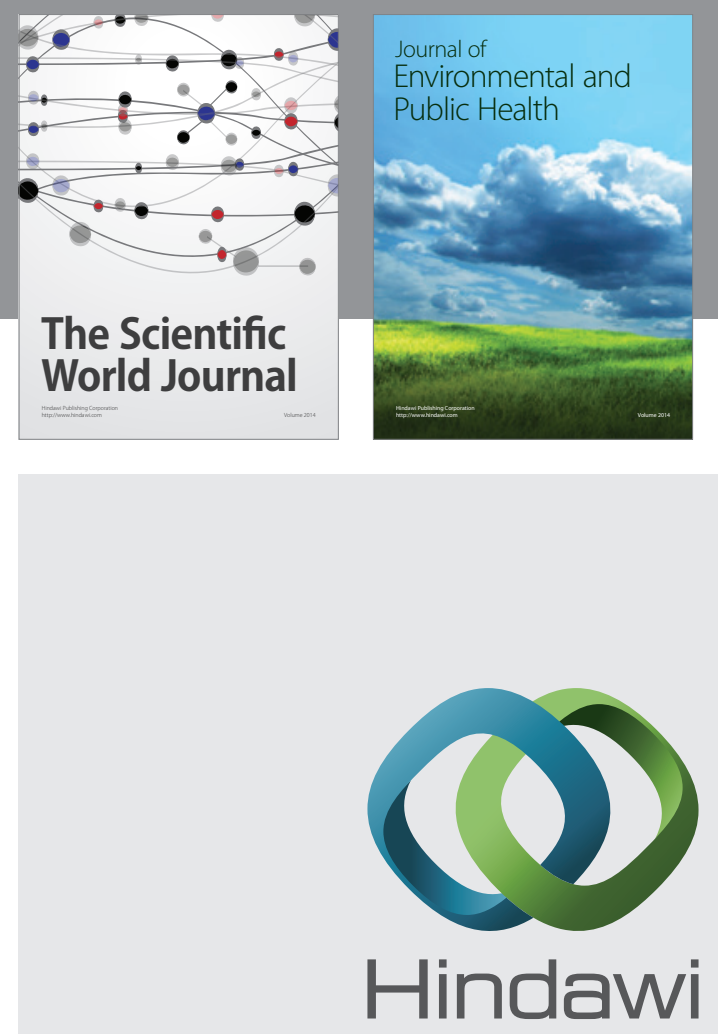

Submit your manuscripts at

http://www.hindawi.com
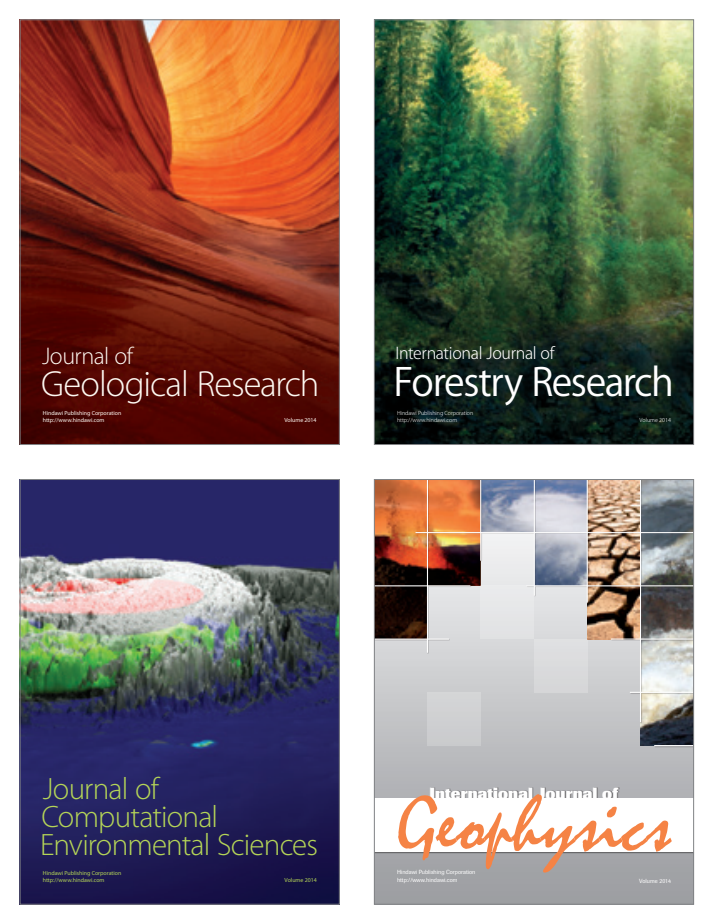
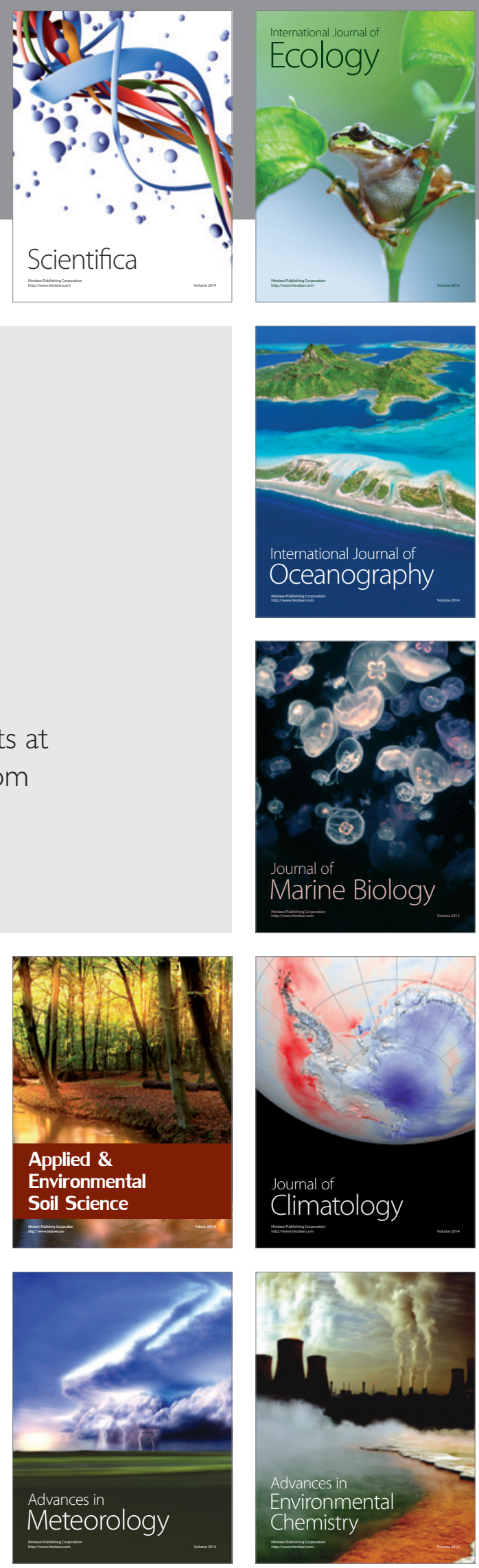